This is a pre-peer reviewed version of the following article: Rissi, G. O.,

Singh, S. P., Burgess, G. and Singh, J. (2008), Measurement and analysis of

truck transport environment in Brazil. Packaging Technology and Science, 21:

231-246. doi: 10.1002/pts.797, which has been published in final form at

http://onlinelibrary.wiley.com/doi/10.1002/pts.797/abstract

\title{
Measurement and Analysis of Truck Transport Environment in Brazil
}

Giovani Otavio Rissi

Perdigão Agroindustrial S/A, Sao Paulo, Brazil

S. Paul Singh

Michigan State University, East Lansing, MI, USA

G. Burgess

Michigan State University, East Lansing, MI, USA

J. Singh

Cal Poly State University, San Luis Obispo, CA, USA

\section{ABSTRACT}

Increasing trade in today's global economy requires packaging to be designed to contain, protect and deliver products without damage during transportation and handling. Vibration forces that occur during transportation are one of the most significant causes of damage during shipping. The objective of this study was to quantify and analyse the vibration that occurs during truck transport in Brazil. The study was done using two types of trucks: small local trucks for local metropolitan distribution areas and larger tractor-trailers for cross-country transportation. Ten metropolitan areas in different regions of Brazil were selected for 1-day trips representing normal delivery. These trips encountered varying road surfaces (asphalt, concrete, stone and dirt). The long distance trips were done on highways that were more than $1200 \mathrm{~km}$ long. The vertical vibration levels were higher than the lateral and longitudinal levels as expected. A composite power density spectrum of all trips is provided in this paper to simulate truck transport in Brazil using random vibration test methods.

KEY WORDS: vibration; truck transport; power density spectrum, Brazil 


\section{INTRODUCTION}

Truck transport is commonly used worldwide for the distribution of goods for trade. Although relatively expensive when compared with bulk shipments by rail and sea, truck transport is usually the most economical way to provide distribution of goods in places where inexpensive (e.g. railways) or natural (e.g. ports, rivers) transport alternatives are not available. The global economy is increasingly demanding that products be distributed on a worldwide basis. International free-trade agreements have leveraged the quality standards and expectations of consumer products to the point that it is not possible to predict anymore where a product will be ultimately sold. For the global economy to flourish, packaging designers need to broaden their knowledge of potential hazards (e.g. vibration) found during transportation to help design and test packages to be shipped on an international scale.

Brazil is the ninth largest economy in the world, based on gross domestic product (GDP) and purchasing power parity (PPP) according to estimates from the International Monetary Fund (IMF). It is also the largest economy in Latin America and the southern hemisphere. The recently reported 15 greatest economies by the IMF are listed in Table 1 (values in US\$ million). ${ }^{1}$

\begin{tabular}{|c|c|c|}
\hline \multicolumn{3}{|c|}{$\begin{array}{l}\text { Table I. GDP in PPP of the } 15 \text { leading } \\
\text { economies in the world }\end{array}$} \\
\hline Rank & Country & GDP (PPP) (\$ million) \\
\hline 1 & USA & 12277583 \\
\hline 2 & China & 9412361 \\
\hline 3 & Japan & 3910728 \\
\hline 4 & India & 3633441 \\
\hline 5 & Germany & 2521699 \\
\hline 6 & UK & | 832792 \\
\hline 7 & France & 1830110 \\
\hline 8 & Italy & $|668| 5 \mid$ \\
\hline 9 & Brazil & I 576728 \\
\hline 10 & Russia & | $57556 \mid$ \\
\hline 11 & Canada & | 104701 \\
\hline 12 & Spain & 1089103 \\
\hline 13 & Mexico & I 072563 \\
\hline 14 & South Korea & 994399 \\
\hline 15 & Indonesia & 977419 \\
\hline
\end{tabular}


Since 2001, the international net trade of Brazil has increased significantly as shown in Figure 1. Brazil's foreign trade is evenly divided among a number of main partners: the European Union (27\%), the USA through North America Free Trade Agreement (26\%), South America (especially within MercosulSouthern Common Market, $25 \%$ ) and Asia (12\%). Other regions make up the remaining $10 \%{ }^{2}$ Brazil's economy is backed by a wide array of natural resources and a diversified infrastructure on the way to modernization. Open regionalism combined with strengthening the multilateral trading system manifests Brazil's fundamental interest in preserving balanced trade and financial ties with the various regions and countries of the world. The result is an increasing net income of the international trade as shown in Figure 1. Geographically, most of the goods produced for export are made in the eastern region of Brazil, where the majority of the people reside. Figure 2 shows the contribution of each Brazilian state to the total national export according to the 2004 data from the Applied Economics Research Institute of Brazil. ${ }^{2}$

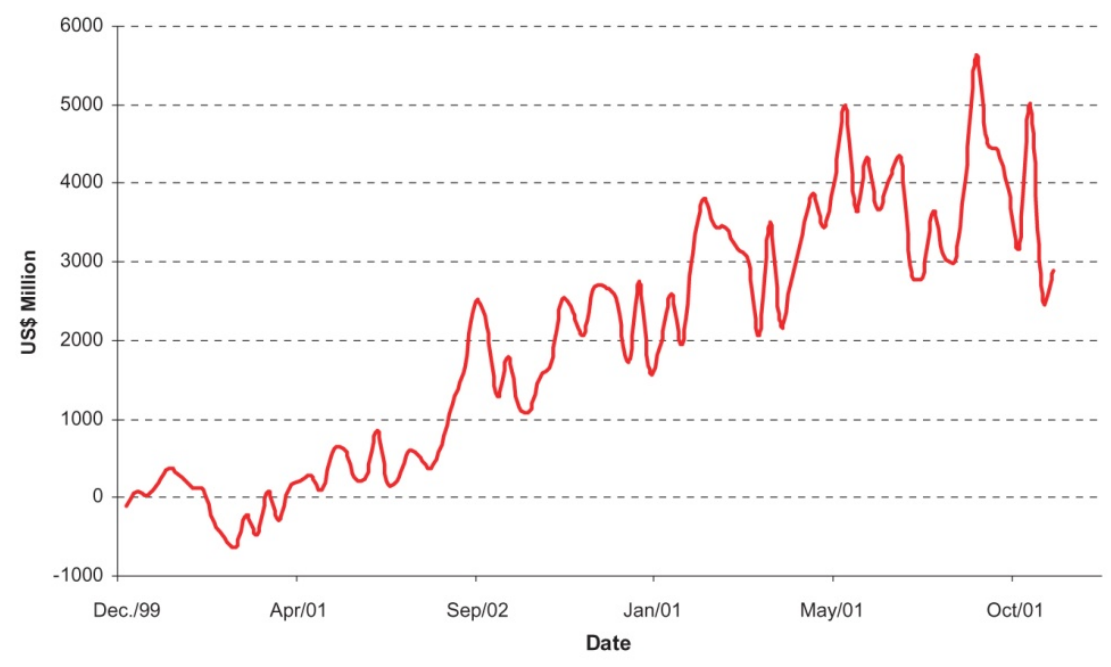

Figure 1. Net international trade of Brazil.

Although most of the world's eyes are currently focused on Asia due to its accelerated development, it is important to have active suppliers in other continents to avoid dependence on one country or region. Sanitary restrictions and political and trade barriers may be imposed quickly to protect local economies 
so that other supply sources could be readily considered to avoid rising prices and low stock. For instance, it is estimated that over 100 million birds have died or been killed in 2004 as a consequence of avian influenza outbreaks. In particular, the impact of import bans on export-dependent countries, such as Thailand, will increase the income vulnerability of small producers as local prices drop sharply. Both Canada and the USA, in addition to nine Asian countries, have also reported outbreaks of bird fl $\mathrm{u}$. These countries account for 4 million tons or $50 \%$ of the world exports of poultry meat (with the USA accounting for nearly $35 \%)$. Chinese exports of poultry were estimated to decline $20 \%$ as a direct consequence of the bird fl u outbreaks. Similarly, cases of bovine spongiform encephalopathy in the USA and Canada has caused countries around the world to ban beef imports from these countries. The USA and Canada account for more than one-quarter of global beef exports (around 1.6 million tons, valued at approximately $\$ 4$ billion). ${ }^{3}$ In Japan, import bans on beef and chicken have led to pork meat prices surging $40 \%$ in 2004 . Also, meat shortages have pushed large importers to diversify suppliers globally in order to protect market share.

Truck transport plays a significant role in moving products from the agricultural and resource-rich regions of Brazil to the port cities. The Brazilian truck fleet is estimated at 1733300 vehicles. ${ }^{4}$ During $2005,61.1 \%$ of the total tonnage of goods transported in Brazil used road transport. 4 It is therefore the most important transport system for the distribution of goods. The volume of goods transported by rail, ships and planes consisted of $20.7,17.8$ and $0.4 \%$, respectively. ${ }^{4}$

There is quite a diversity in the types of road surfaces used by trucks in Brazil. The most common types of road surfaces are asphalt, concrete, dirt (unpaved) and stone. Stone roads are almost exclusively found in the urban environment because their construction is labor intensive. Asphalt and concrete are more common for expressways (highways) connecting major cities. Figure 3 shows the various types of road conditions measured in this study. Toll roads account for $10803 \mathrm{~km}$ and are deemed to be better 
than public roads because the toll tax is reinvested in the road. Even among paved surfaces, potholes and undulations due to heavy-load traffic and poor construction occur, causing severe impacts or transient shocks during truck vibration. Table 2 shows the distribution of paved and unpaved roads in Brazil.

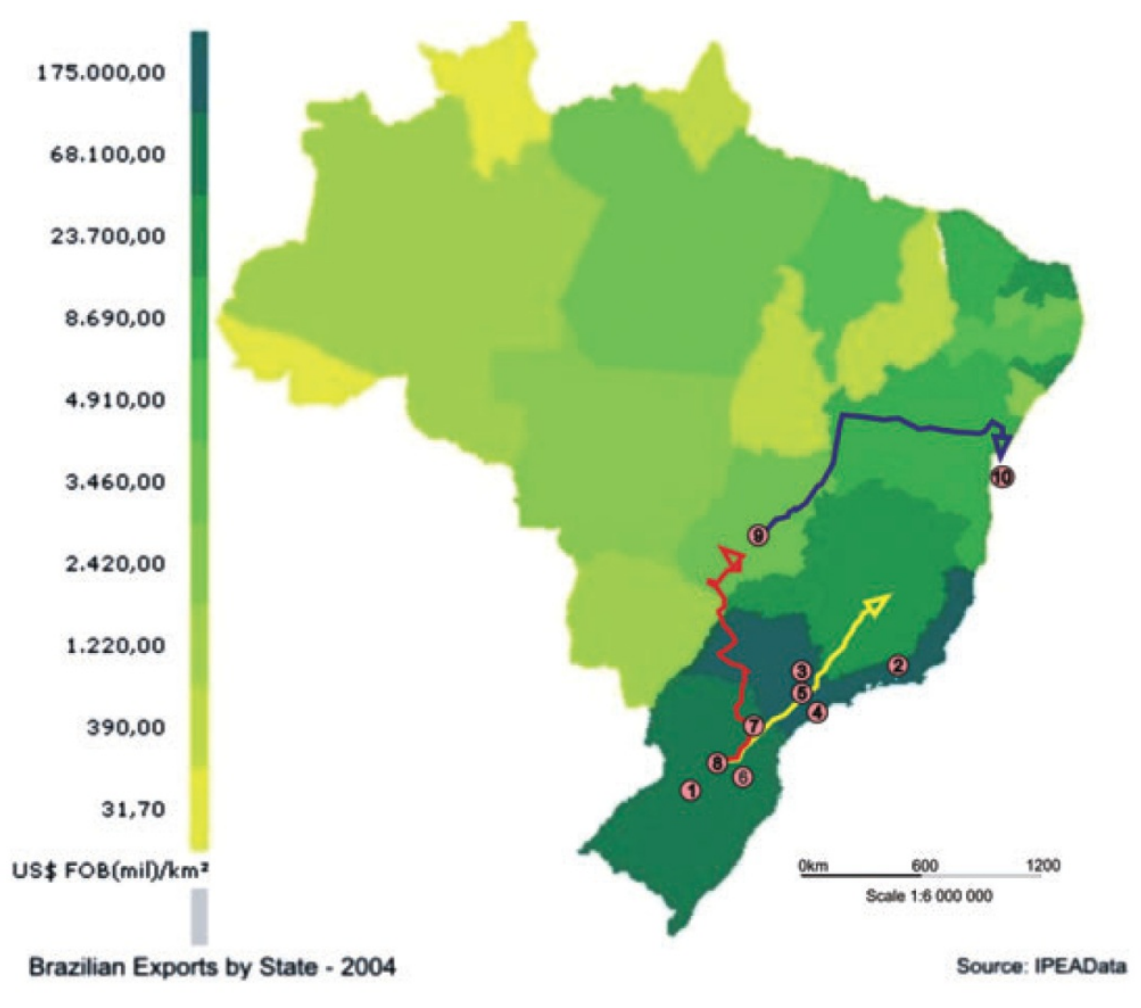

Figure 2. Exports of Brazil by state and locations of measurement of metropolitan distribution and cross-country trips.

For economical and environmental reasons, packaging systems have been reduced to minimal levels in order to provide the required protection. The challenge of surviving the zero-damage goal has become greater as a consequence of the global economy, as most goods are distributed virtually everywhere in the world. ${ }^{5}$ Therefore, measuring the distribution environment is a key factor in developing appropriate vibration testing methods that can be used to develop optimum protective packaging. Not designing according to realistic shipping conditions may result in either over-packaging (where the test level is 

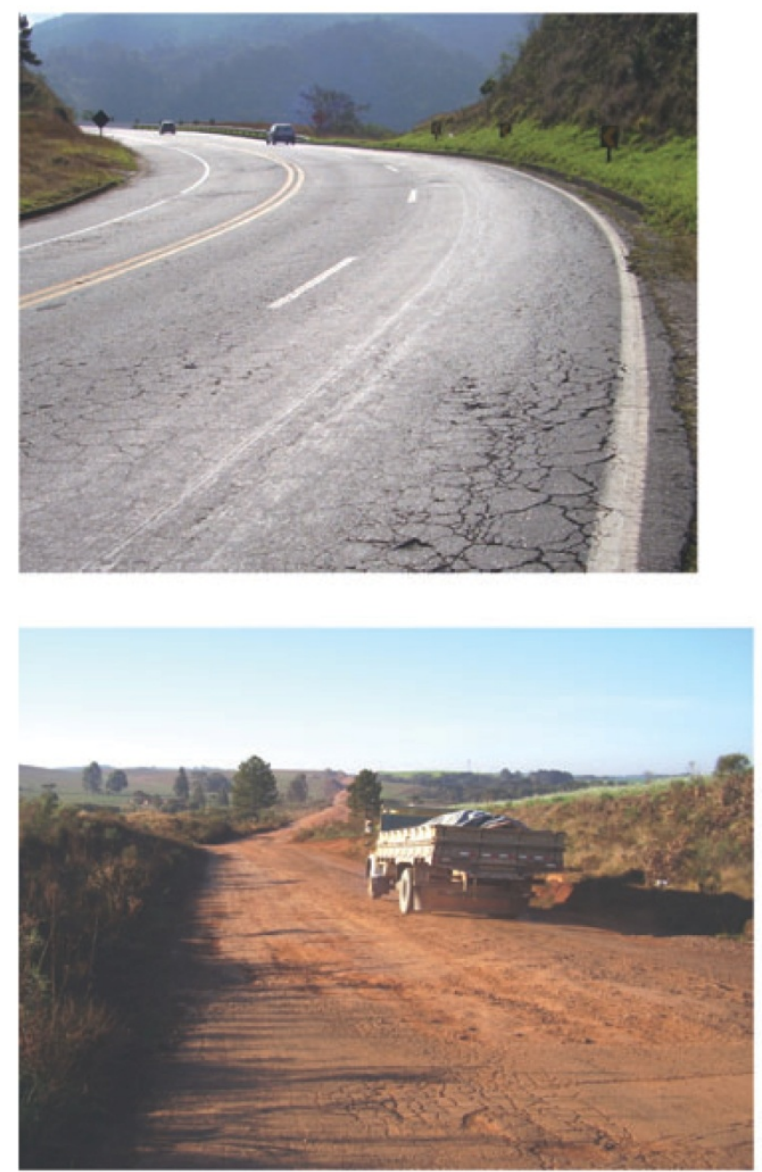
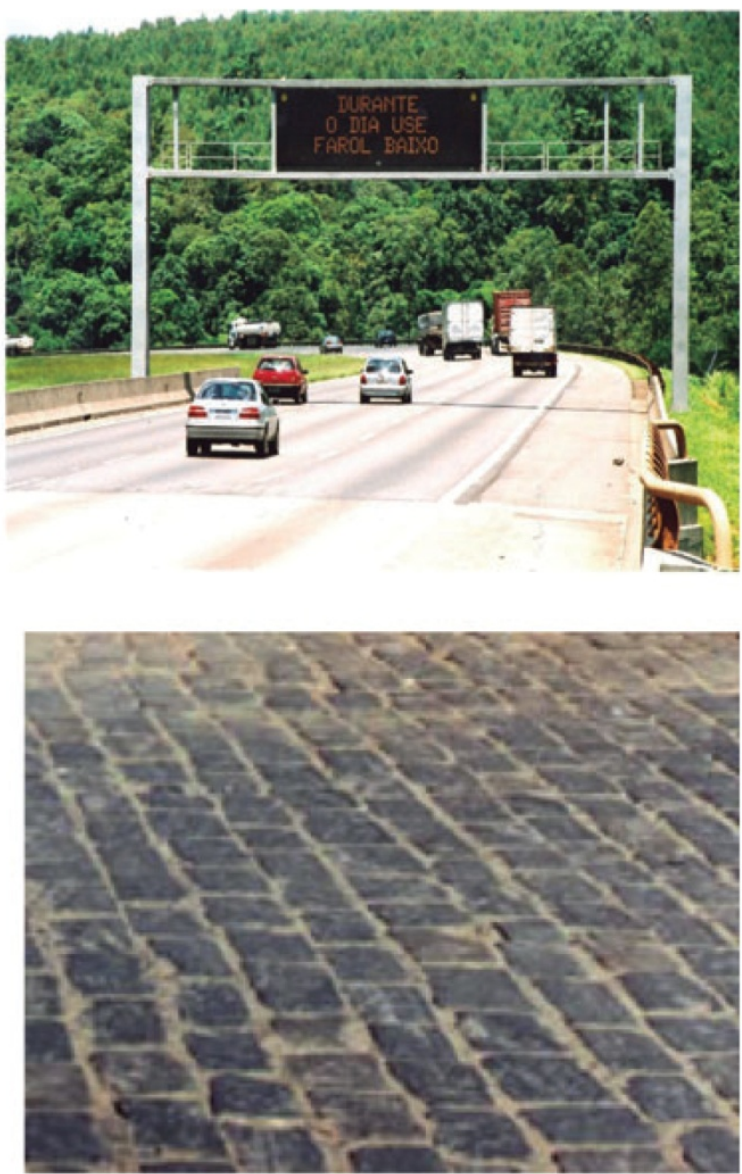

Figure 3. Types of road surfaces in Brazil: asphalt, concrete, stone and dirt (clockwise from top left).

more severe than the environment) or product damage due to under-packaging (where test levels are lower in intensity than the shipping environment).

Since 2000, vibration measurement studies have been done in various regions around the world (China, Thailand, India and Europe) in order to develop data to define a 'global distribution environment' ${ }^{6}$ Data from Brazil is important, as this is the leading economy in Latin America. Small trucks for metropolitan distribution and larger trucks for cross-country distribution were used in this study to collect data for different payloads, truck types, speeds and road surfaces.

Vibration occurs whenever a spring-mass system (e.g. the truck mass on its suspension) is in motion. A large tractor-trailer has different spring-mass systems acting together. They are the pneumatic tires, the 


\begin{tabular}{|lcccc|}
\hline \multicolumn{5}{c}{ Table 2. Distribution of road types in Brazil } \\
Road type & Paved & Unpaved & Total & $\%$ paved \\
\hline Federal & 57933 & 14777 & 72710 & 79.7 \\
State transitory & 17049 & 7277 & 24326 & 70.1 \\
State & 98377 & 109963 & 208340 & 47.2 \\
City & 22735 & 1281965 & 1304700 & 1.7 \\
Total & 196094 & 1413982 & 1610076 & 12.2 \\
Source: CNT - Brazilian National Transport Confederation. & & \\
\hline \multicolumn{5}{l}{} \\
\hline
\end{tabular}

trailer floor and the suspension. Damage usually occurs as a consequence of magnification of truck vibration caused by cushioned product packages. When the truck bed vibration frequency is close to the product-package natural frequency, the system starts to exhibit a condition called 'resonance', resulting in large vibration forces from the truck bed (input) to the product (output). These conditions often result in damage to the packaged product. Examples of vibration-related product damage from truck shipments include fatigue, mechanical failure, scuffing, static charge buildup, undesirable product settling, phase separation and leaking of fluids.

\section{EXPERIMENTAL DESIGN AND SET-UP}

\section{Vehicles and trips}

Table 3 shows the various shipments measured. There were large variations in trip distance, gross weight and truck type. All trucks had leaf spring suspensions and insulated trailers. The products transported in these shipments were food products in refrigerated or frozen conditions. The routes are also graphically shown in Figure 2. All metropolitan regions used six-wheeled trucks (two axles), except for measurement 7 (Curitiba - PR), which was done using a 10-wheeled (three axles) trailer. Figure 4 shows the metropolitan distribution trucks, and Figure 5 shows the cross-country trucks. 
Table 3. Details of measurements of truck environment in Brazil

\begin{tabular}{|c|c|c|c|c|}
\hline Shipment date & Location & $\begin{array}{l}\text { Load } \\
(\mathrm{kg})\end{array}$ & $\begin{array}{l}\text { Distance } \\
(\mathrm{km})\end{array}$ & Vehicle \\
\hline & & \multicolumn{2}{|c|}{ Metropolitan regions } & \\
\hline 1. 24 August 2006 & Passo Fundo - RS & 6020 & 186 & $\begin{array}{l}\text { Mercedes } 1418 \text { (177 h.p. @2200 rpm, maximum net } \\
\text { payload of I3 } 990 \mathrm{~kg})\end{array}$ \\
\hline 2. 29 August 2006 & Rio de Janeiro - RJ & 462.68 & 103 & $\begin{array}{l}\text { Mercedes-Benz } 710(110 \text { h.p. @ } 2300 \text { rpm, maximum } \\
\text { net payload of } 3770 \mathrm{~kg})\end{array}$ \\
\hline 3. 30 August 2006 & Campinas - SP & 2150 & 94 & $\begin{array}{l}\text { Volkswagen 8-150 (150 h.p. @ } 2500 \text { rpm, maximum } \\
\text { net payload of } 8150 \mathrm{~kg} \text { ) }\end{array}$ \\
\hline 4. 31 August 2006 & Santos - SP & 1264.24 & 145 & $\begin{array}{l}\text { Iveco } 50-13 \text { (I25 h.p. @3600 rpm, maximum net } \\
\text { payload of } 3270 \mathrm{~kg})\end{array}$ \\
\hline 5. I September 2006 & São Paulo - SP & 1997 & 51 & $\begin{array}{l}\text { Volkswagen 8-120 (II } 5 \text { h.p. @2400 rpm, maximum } \\
\text { net payload of } 7750 \mathrm{~kg} \text { ) }\end{array}$ \\
\hline 6. 6 September 2006 & Lages - SC & 3423 & 459 & $\begin{array}{l}\text { Iveco Daily 70-I2 (I25 h.p. @3600 rpm, maximum } \\
\text { net payload of 4|40 kg) }\end{array}$ \\
\hline 7. 8 September 2006 & Curitiba - PR & 2921 & 188 & $\begin{array}{l}\text { Mercedes } 1620 \text { - } 10 \text { wheels }(231 \text { h.p. @2200 rpm, } \\
\text { maximum net payload of } 16460 \mathrm{~kg} \text { ) }\end{array}$ \\
\hline 8. 19 September 2006 & Videira - SC & 1180 & 120 & $\begin{array}{l}\text { Iveco Daily 49-12 (122 h.p. @3600 rpm, maximum } \\
\text { net payload of } 3120 \mathrm{~kg} \text { ) }\end{array}$ \\
\hline 9. 10 October 2006 & Goiânia - GO & 2700 & 42 & $\begin{array}{l}\text { Mercedes-Benz } 710(110 \text { h.p. @2300 rpm, } \\
\text { maximum net payload of } 3770 \text { kg) }\end{array}$ \\
\hline \multirow[t]{2}{*}{ 10. 13 October 2006} & Salvador - BA & 1629 & 91 & $\begin{array}{l}\text { Iveco Daily } 35-10 \text { (103 h.p. @3600 rpm, maximum } \\
\text { net payload of } 2390 \mathrm{~kg})\end{array}$ \\
\hline & & \multicolumn{2}{|c|}{ Long distance trips } & \\
\hline $\begin{array}{l}\text { Yellow - } 20 \\
\text { September } 2006\end{array}$ & $\begin{array}{l}\text { Videira (SC)- Belo } \\
\text { Horizonte (MG) }\end{array}$ & 19260 & 1306 & $\begin{array}{l}\text { Tractor Scania } 400 \text { (400 h.p.) - year 2003; semi- } \\
\text { trailer Recrusul - year I } 999\end{array}$ \\
\hline $\begin{array}{l}\text { Red }-27 \\
\quad \text { September } 2006\end{array}$ & $\begin{array}{l}\text { Videira (SC)- } \\
\text { Rio Verde (GO) }\end{array}$ & 26150 & 1481 & $\begin{array}{l}\text { Tractor Mercedes } 1935 \text { (326 h.p.) - year 1997; } \\
\text { semi-trailer Randon - year } 1997\end{array}$ \\
\hline $\begin{array}{l}\text { Black - } 10 \\
\text { October } 2006\end{array}$ & $\begin{array}{l}\text { Goiânia (GO)- } \\
\text { Salvador (BA) }\end{array}$ & 17960 & 1848 & $\begin{array}{l}\text { Tractor Scania } 380 \text { ( } 380 \text { h.p. }) \text { - year 2005; semi- } \\
\text { trailer - Randon year } 2006\end{array}$ \\
\hline
\end{tabular}

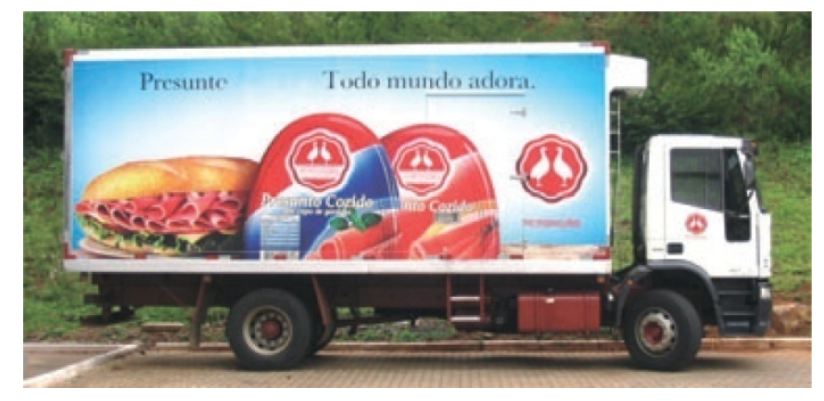

Figure 4. Metropolitan distribution truck

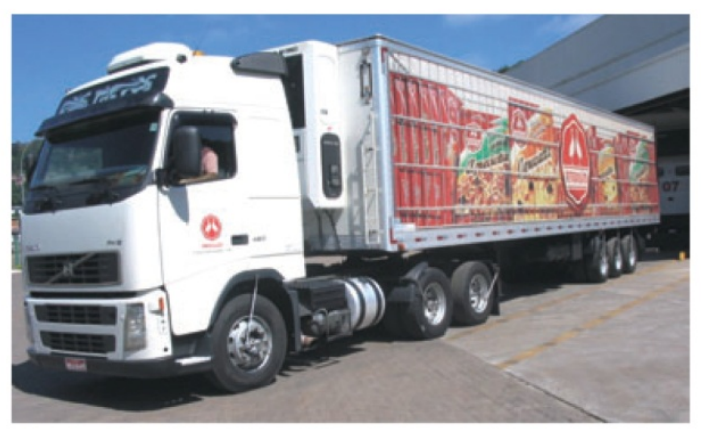

Figure 5. Cross-country transport truck with three axles. 


\section{Measurement equipment}

The instrument used to measure vibration was a model EDR-3C data recorder manufactured by Instrumented Sensor Technology, Okemos, MI, USA. In addition, an online Global Positioning Satelite tracking system developed by Autotrac (Brasília - DF, Brazil) and OmniSAT (Qualcomm Inc., San Diego, California, USA) was used to reference the actual location of the trailers at any given instant to the measured vibration. This allowed the authors to exclude periods of measurement when the trailer was stationary during loading and unloading. The data recorders were mounted on the undercarriage in the middle section and at the rear location of the trailer (Figure 6).

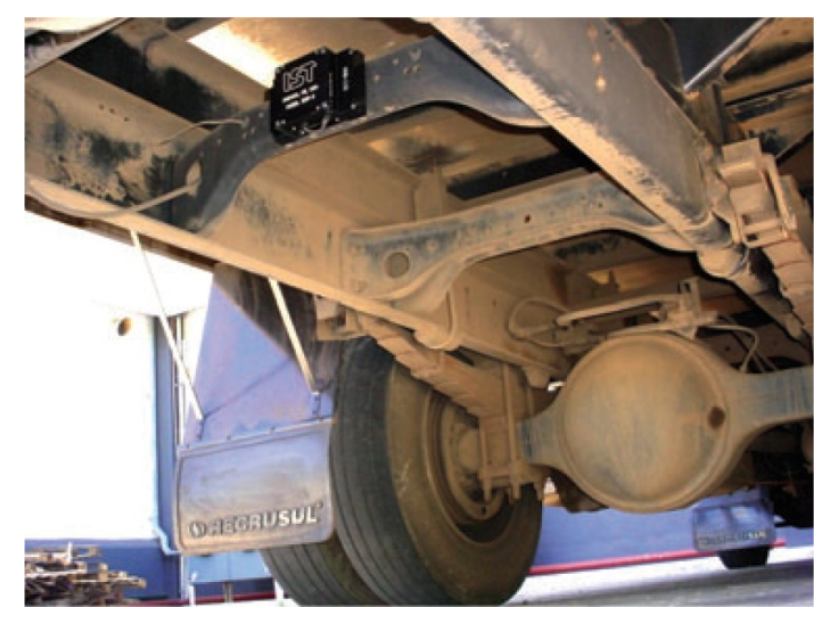

Figure 6. Mounting location of vibration recorder.

The following set-up parameters were used for all three axes (vertical, lateral and longitudinal):

- Pre-trigger length (samples): $32 \mathrm{~ms}$

- Maximum length (samples): $2730.7 \mathrm{~ms}$

- Dead time after event: $1 \mathrm{~s}$

- Sampling rate: 750 samples per second

- Trigger level: $0.25 \mathrm{G}$

- Data retention mode: overwrite 
All shipments were conducted along normal shipping routes and while delivering actual loads. For metropolitan shipments, the truck speeds ranged from 20 to $60 \mathrm{~km} / \mathrm{h}$. For cross-country shipments using expressways, the speeds ranged from 70 to $100 \mathrm{~km} / \mathrm{h}$.

\section{DATA AND RESULTS}

The data obtained from the recorders were analysed using the Dynamax software package developed by Instrumented Sensor Technology. The results of the vibration data analysis are presented as power density spectra. A power density spectrum is a plot of energy (power density) versus frequency. ${ }^{5}$ This is commonly used to measure and compare vibration levels in various global studies. ${ }^{6,7}$

The levels of acceleration occur in a random manner over a range of frequencies. The average power density (PD) within a band of frequencies is calculated as follows:

$P D=\frac{1}{B W} \sum_{i=1}^{n}\left(R M S G_{i}^{2}\right) / n$

where $G_{i}$ is a sampled acceleration value measured in $g^{\prime}$ s within a bandwidth (BW) of frequencies, and $n$ is the number of samples. ${ }^{8}$ The corresponding power density levels are then plotted against the centre frequency of the bandwidth to develop the power density spectra for the data set analysed. For this study, a bandwidth of $1.875 \mathrm{~Hz}$ was used.

The spectra analysed with the described method can be used to compare levels of vibration and frequencies for different trucks, payloads, geographical regions and logistical systems. The raw data for a shipment consisted of vibration levels sampled and recorded in the vertical, lateral and longitudinal directions above the trigger level. The root mean square acceleration $\left(G_{\mathrm{rms}}\right)$ was also calculated for each orientation and trip. This is the square root of the area under the Power Spectral Density plot and represents the overall intensity of vibration across all frequencies. 
The results from this study are presented in the form of four power density spectra for each measurement. These are shown in Figures 7-19. Figures 7-16 are the various inner city metropolitan shipments. These trips varied significantly in the quality of road surfaces as well as travel speeds. Some of these trips produced significantly higher vertical vibration levels than others. Figures 17-19 represent

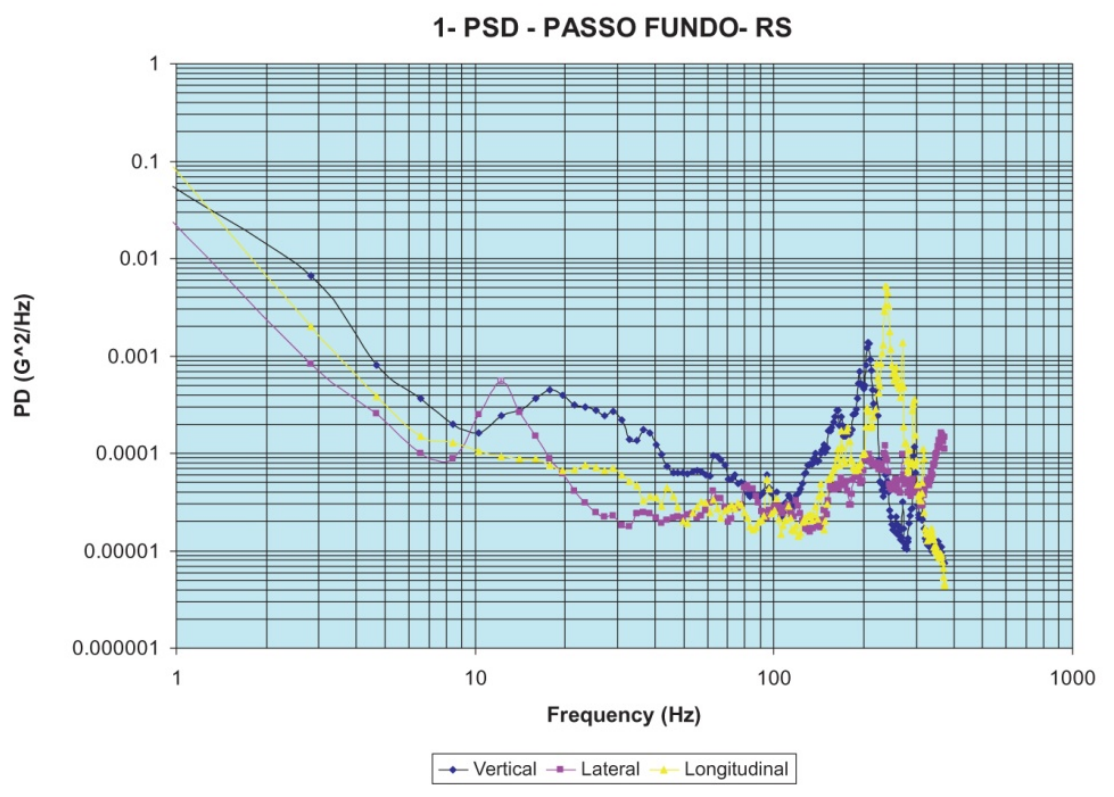

Figure 7. PSD plot for measurement 1 - Passo Fundo (RS). Grms: vertical $=0.3449$; lateral $=0.2198$; longitudinal $=0.4438$

2- PSD - RIO DE JANEIRO - RJ

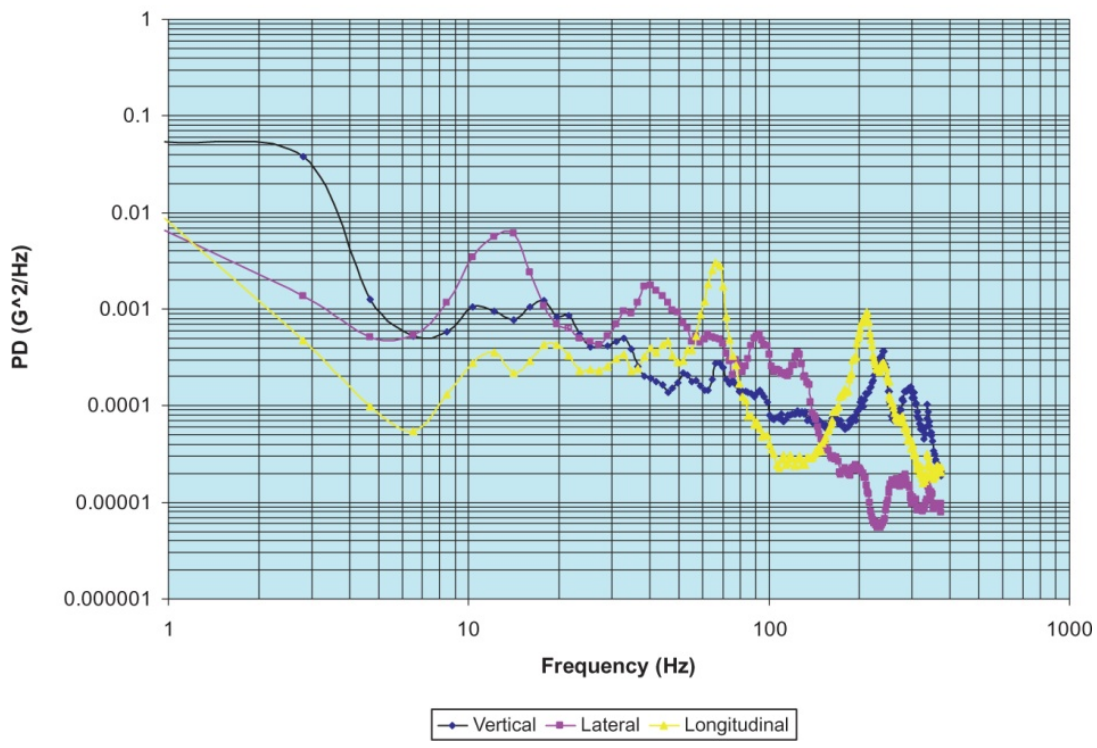

Figure 8. PSD plot for measurement 2 - Rio de Janeiro (RJ). Grms: vertical $=0.4291$; lateral $=0.3364$; longitudinal $=0.3092$. 


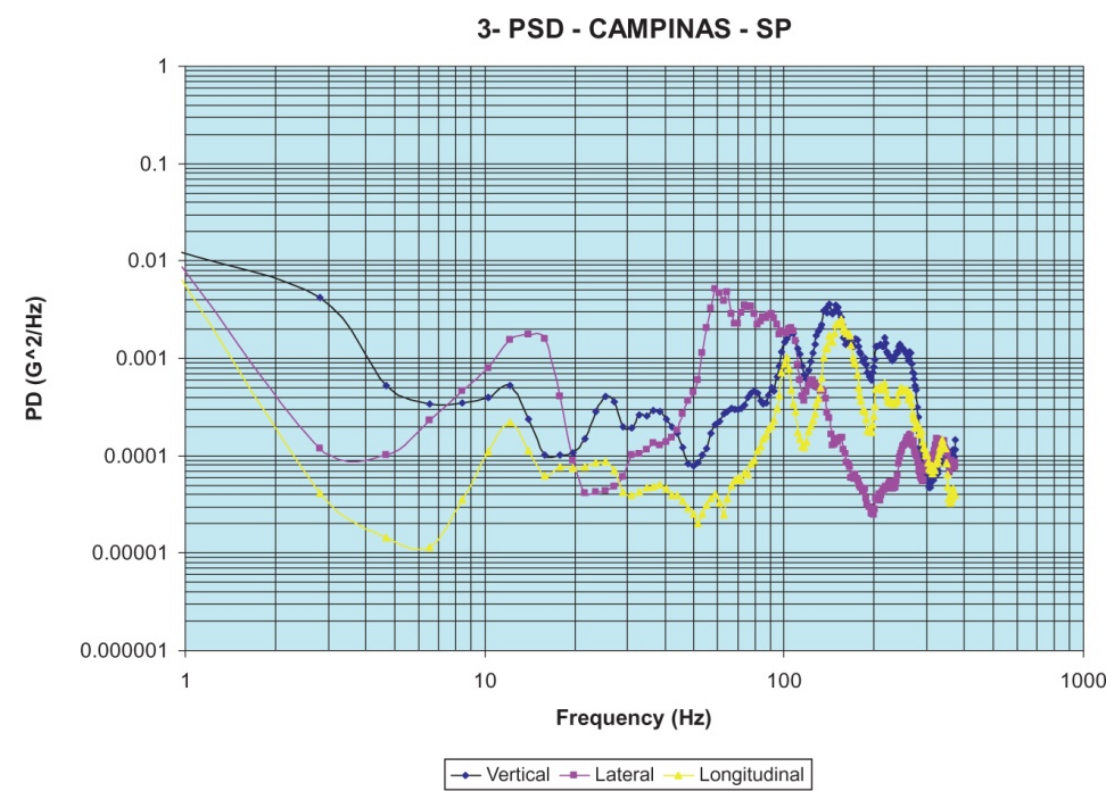

Figure 9. PSD plot for measurement 3 -Campinas (SP). Grms: vertical $=0.5591$; lateral $=0.4699$; longitudinal $=0.3799$.

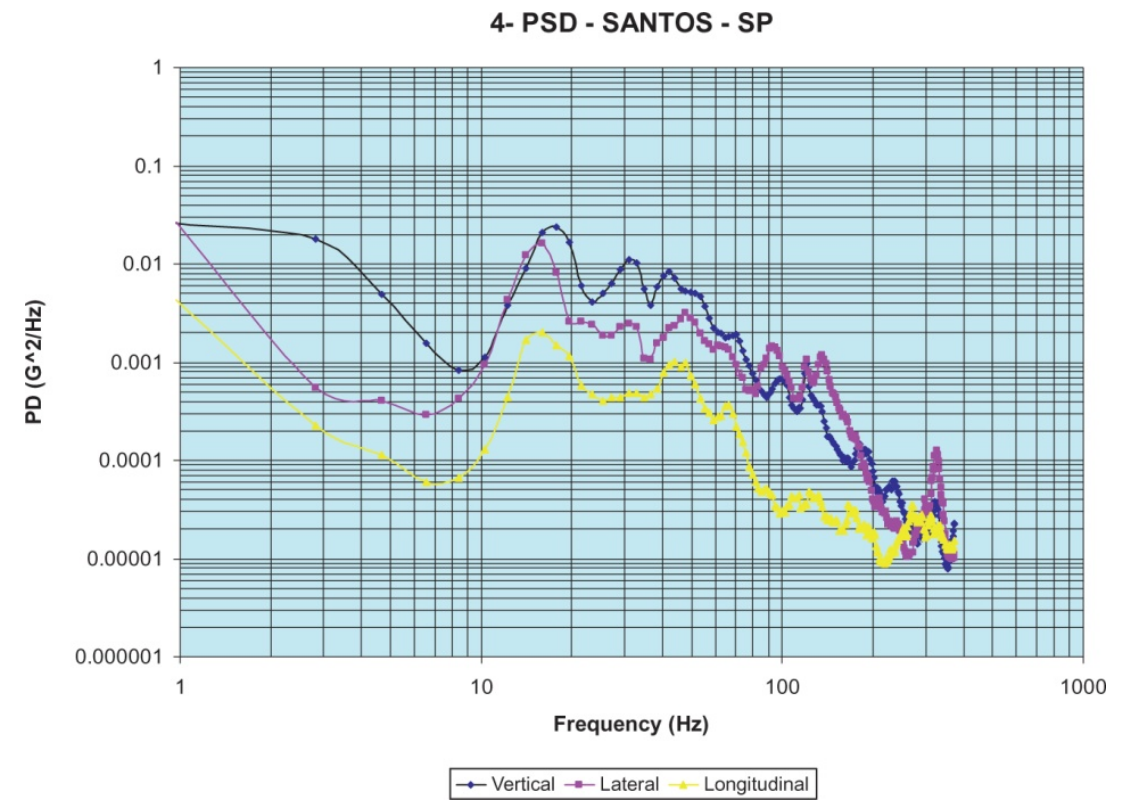

Figure 10. PSD plot for measurement 4 - Santos (SP). Grms: vertical $=0.7206$; lateral $=0.5377$; longitudinal $=0.2286$. 


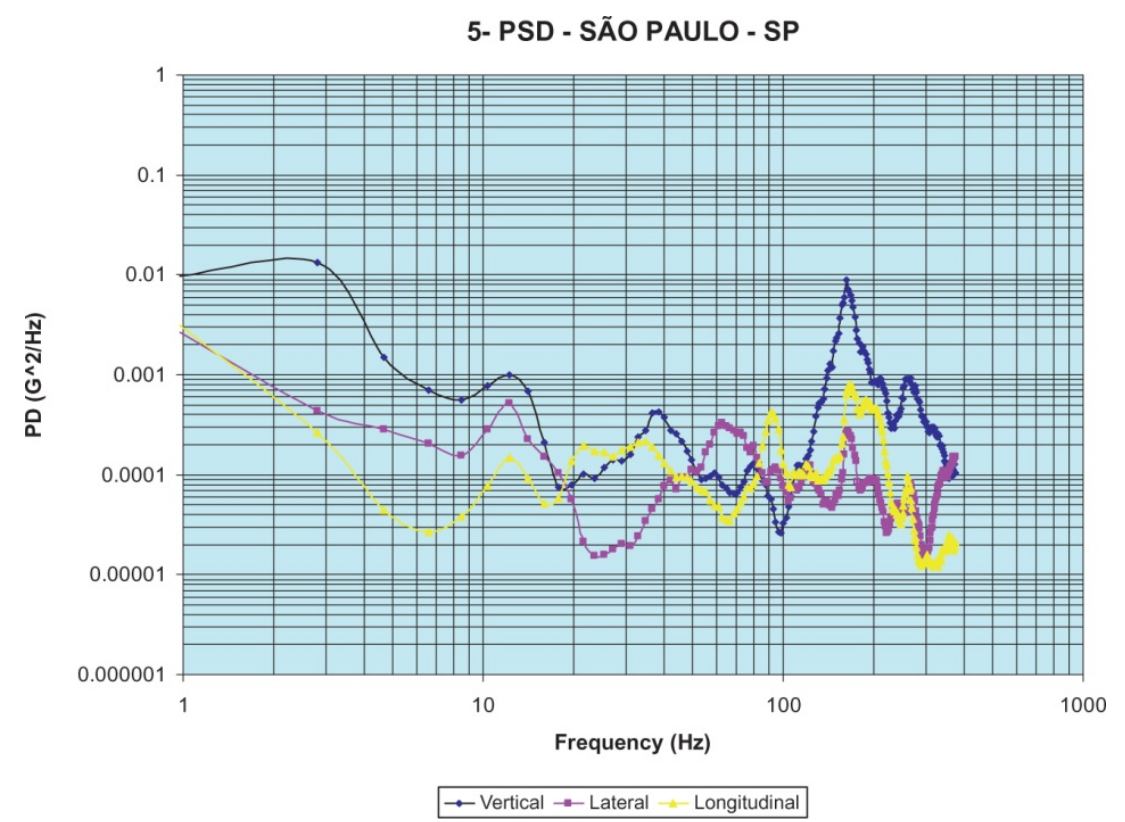

Figure 11. PSD plot for measurement 5 - São Paulo (SP). Grms: vertical $=0.5706$; lateral $=0.1958$; longitudinal $=0.2400$

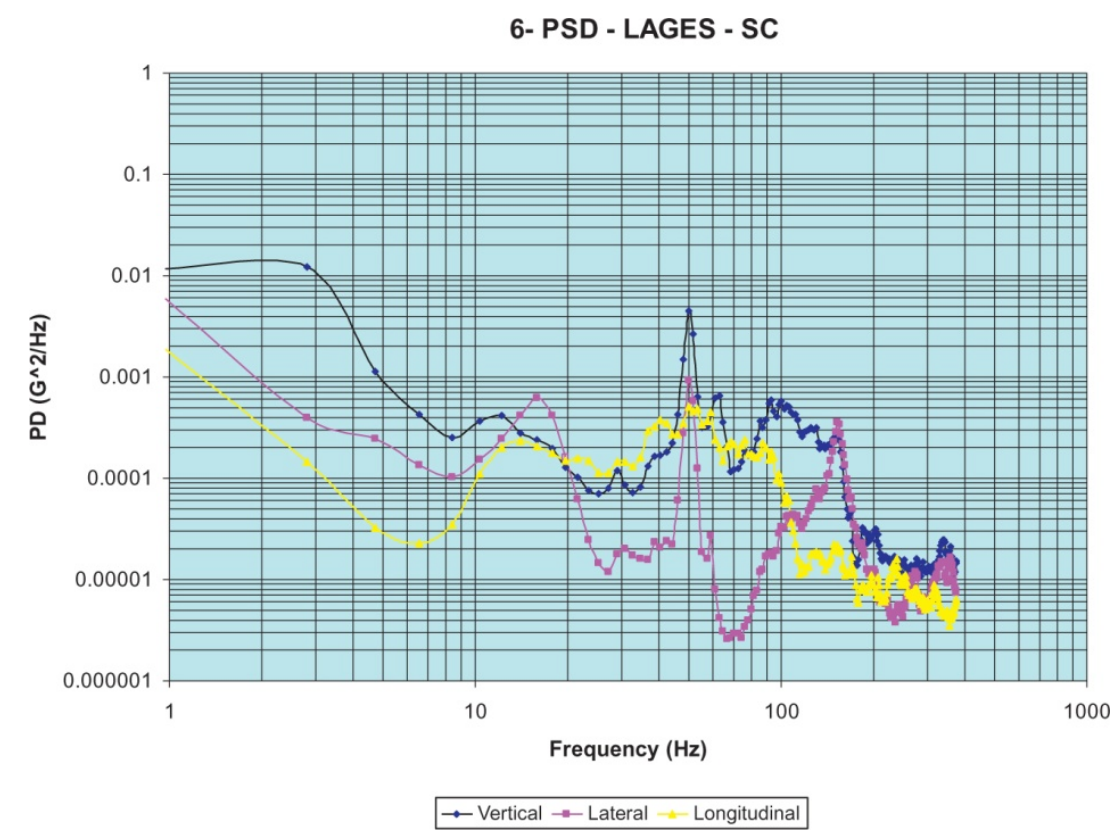

Figure 12. PSD plot for measurement 6 - Lages (SC). Grms: vertical $=0.3142$; lateral $=0.1608$; longitudinal $=0.1609$. 


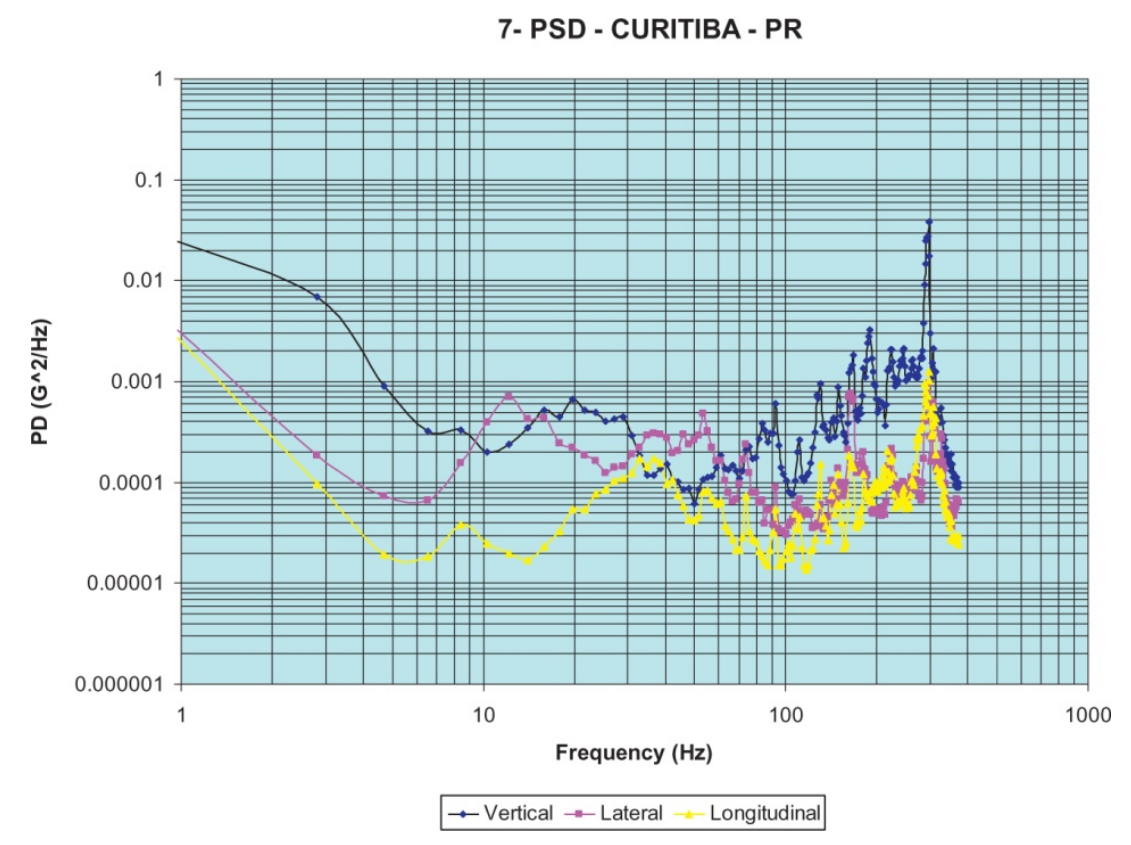

Figure 13. PSD plot for measurement 7 -Curitiba $(P R)$. Grms: vertical $=0.7621$; lateral $=0.2462$; longitudinal $=0.2172$.

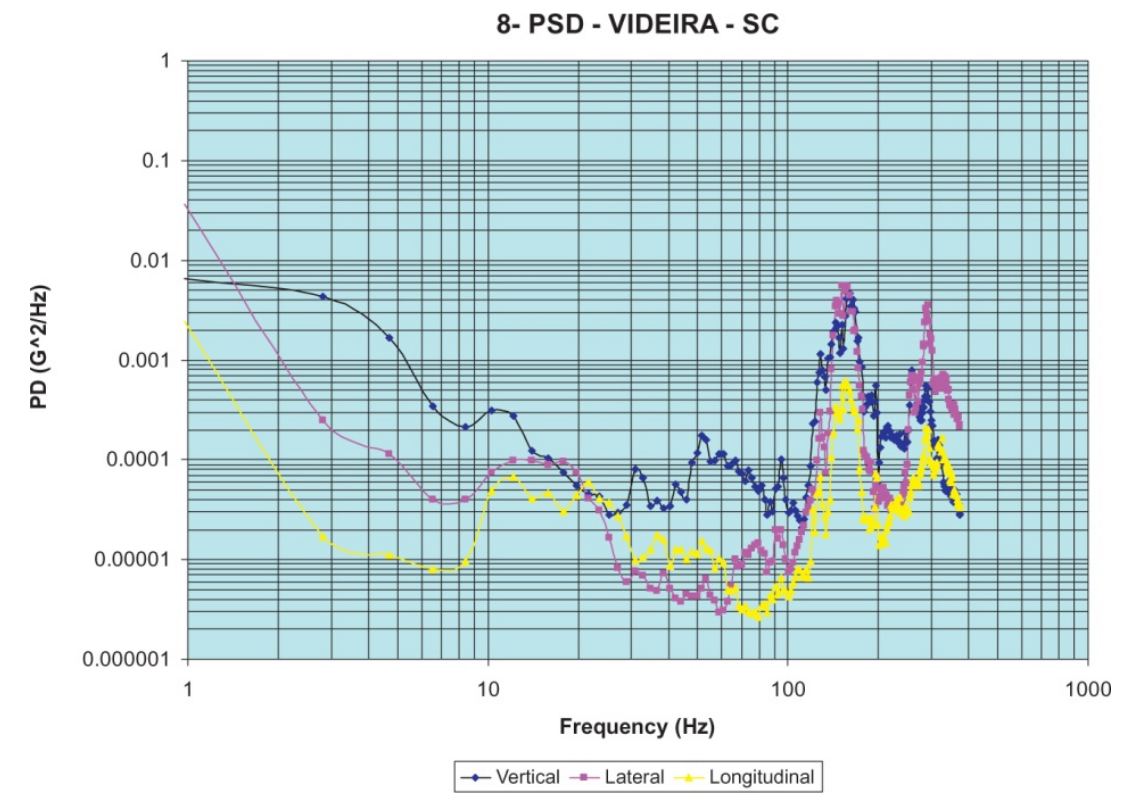

Figure 14. PSD plot for measurement 8 -Videira (SC). Grms: vertical $=0.4193$; lateral $=0.5100$; longitudinal $=0.1739$. 


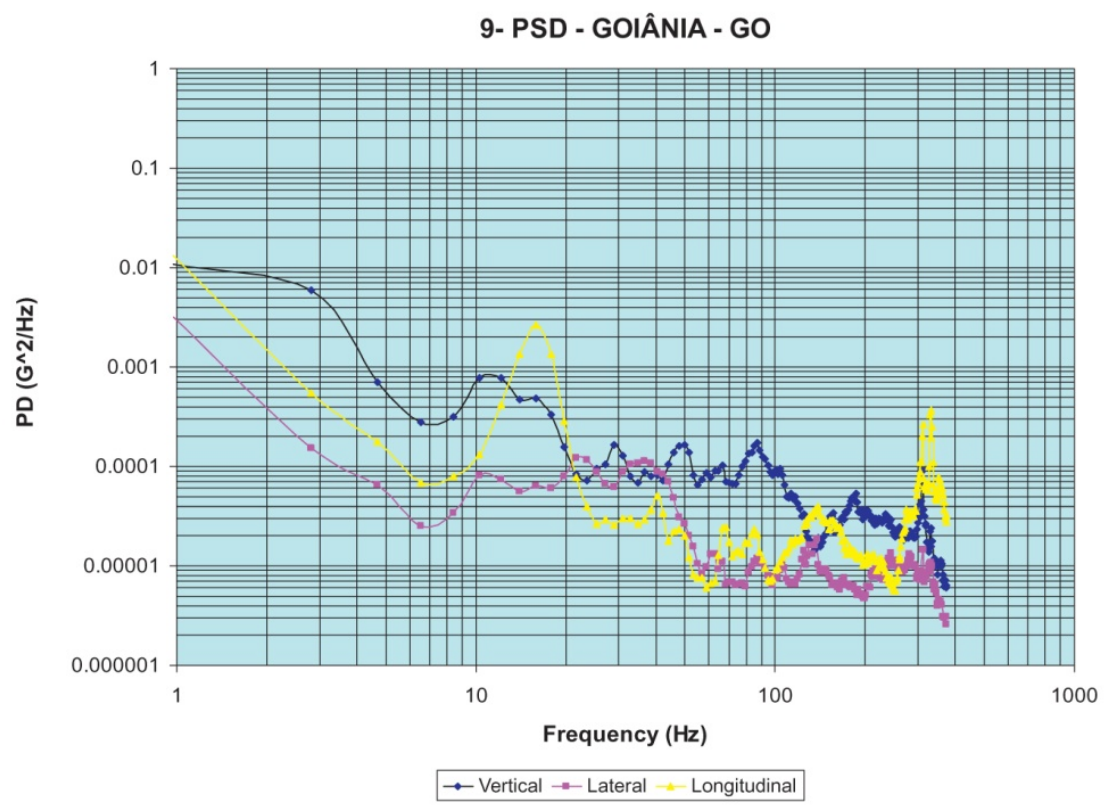

Figure 15. PSD plot for measurement 9 - Goiânia (GO). Grms: vertical $=0.2127$; lateral $=0.0995$; longitudinal $=0.1993$.

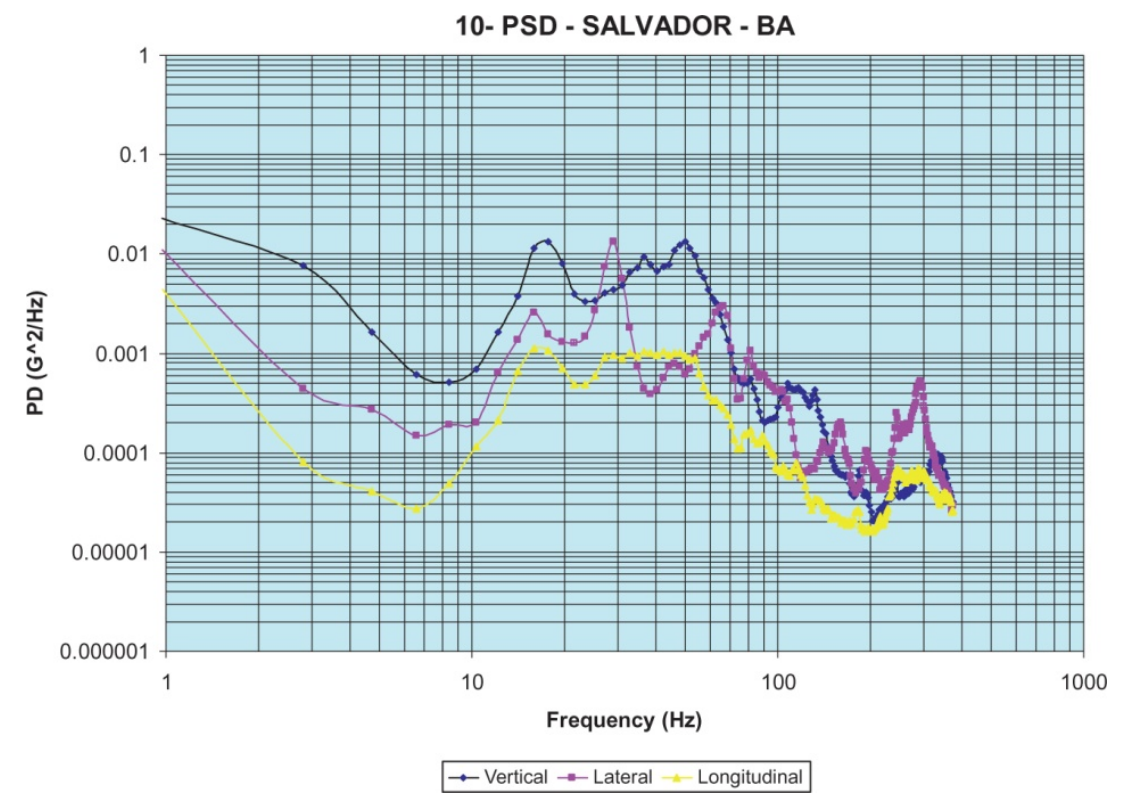

Figure 16. PSD plot for measurement $10-$ Salvador $(B A) . G_{r m s}$ : vertical $=0.6804$; lateral $=0.4388$; longitudinal $=0.2508$. 


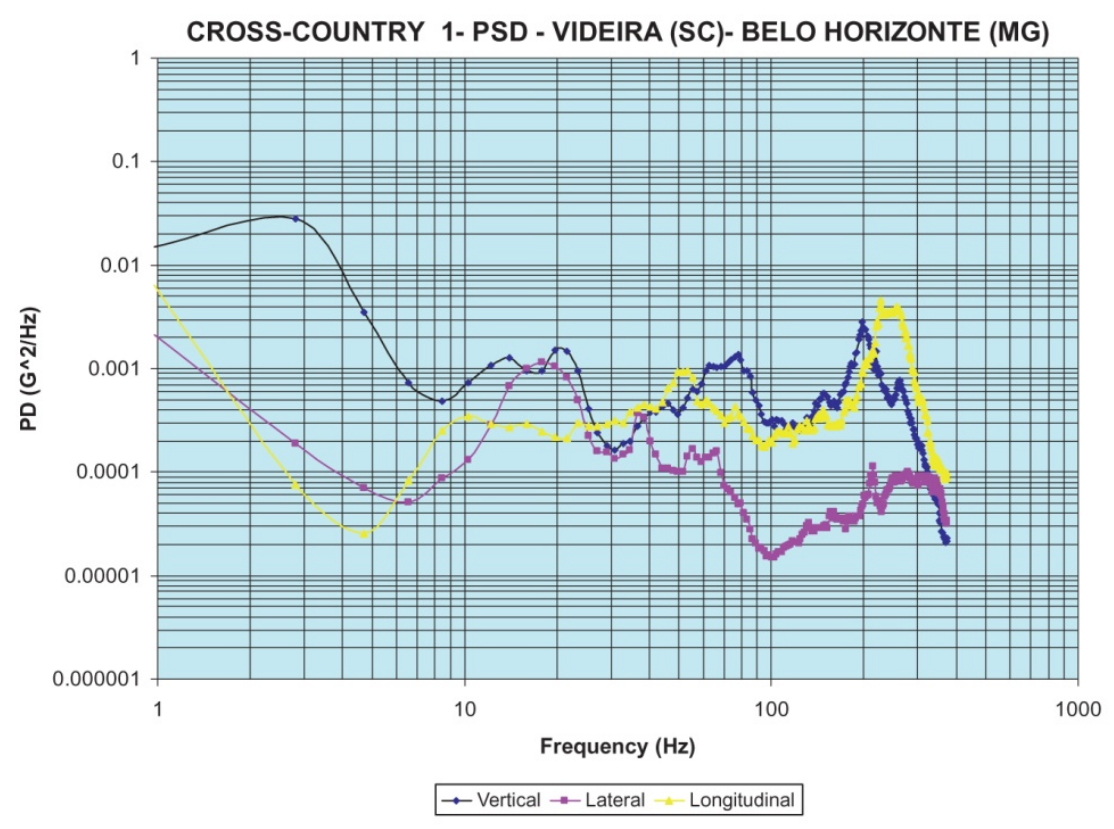

Figure 17. PSD plot for measurement 1 - long distance trip: Videira (SC) to Belo Horizonte (MG). $G_{r m s}$ : vertical $=0.5393$; lateral $=0.1944$; longitudinal $=0.5798$.

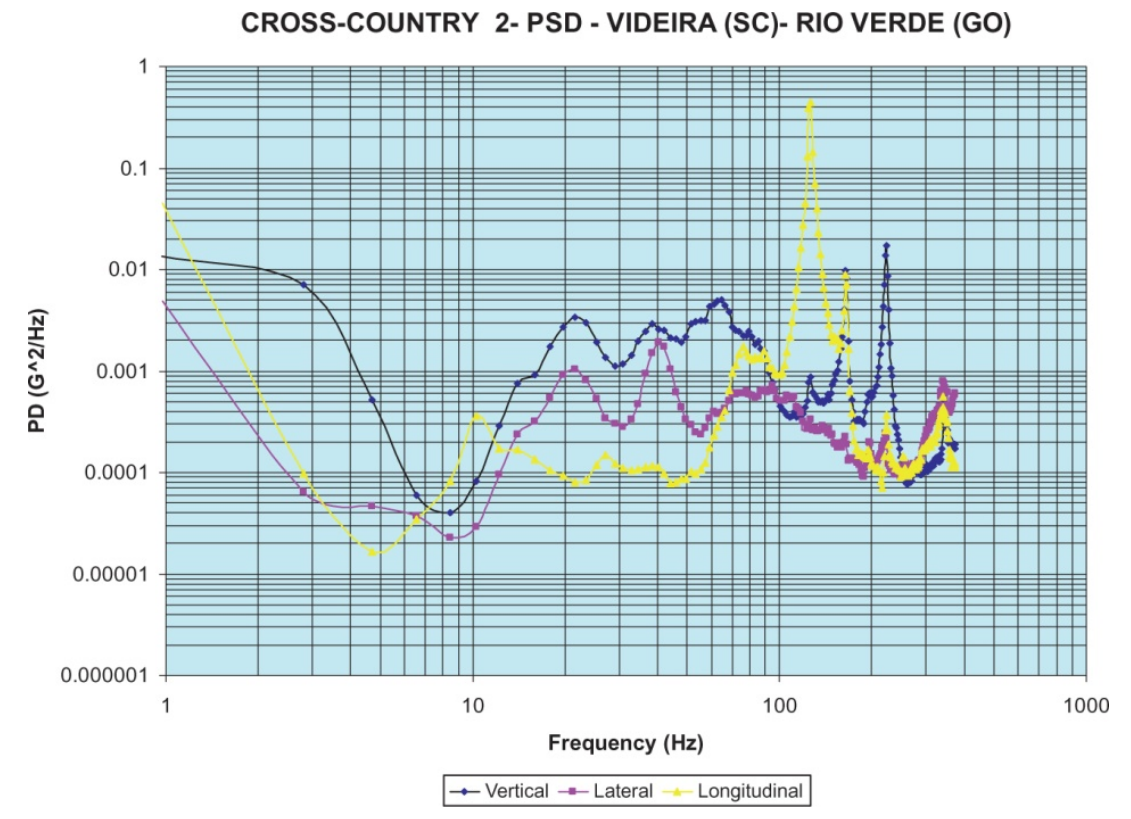

Figure 18. PSD plot for measurement 2 - long distance trip: Videira (SC) to Rio Verde (GO). Grms: vertical $=0.6943$; lateral $=0.3625$; longitudinal $=1.6828$. 


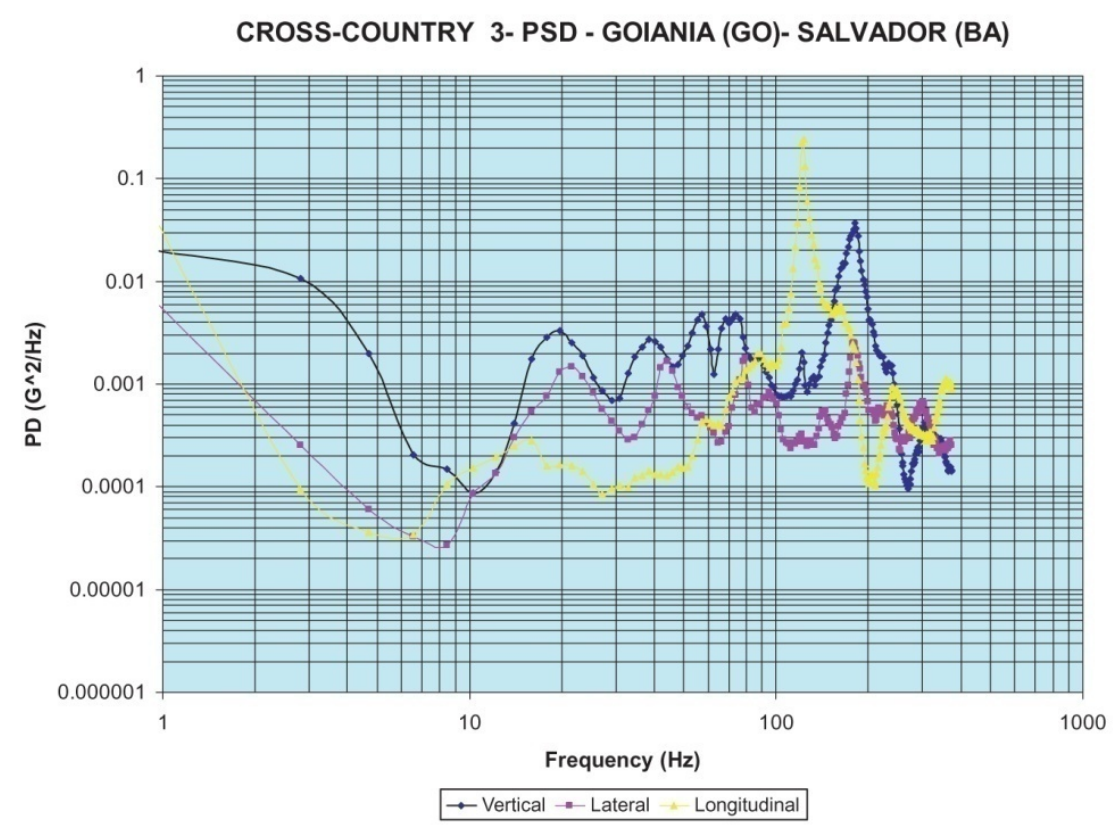

Figure 19. PSD plot for measurement 3 - long distance trip: Goiânia (SC) to Salvador (BA). Grms: vertical $=1.1239$; lateral $=0.4601$; longitudinal $=1.4917$.

the three long distance highway measurements. The data in two of these shipments show extremely high vibration levels in the longitudinal direction at around 110-125 Hz (Figures 18 and 19). These two trailers had low bumpers at the rear of the trailer that produced resonant conditions at these frequencies when contacting the road surface during turns and going over bumps. This is shown in Figure 20.
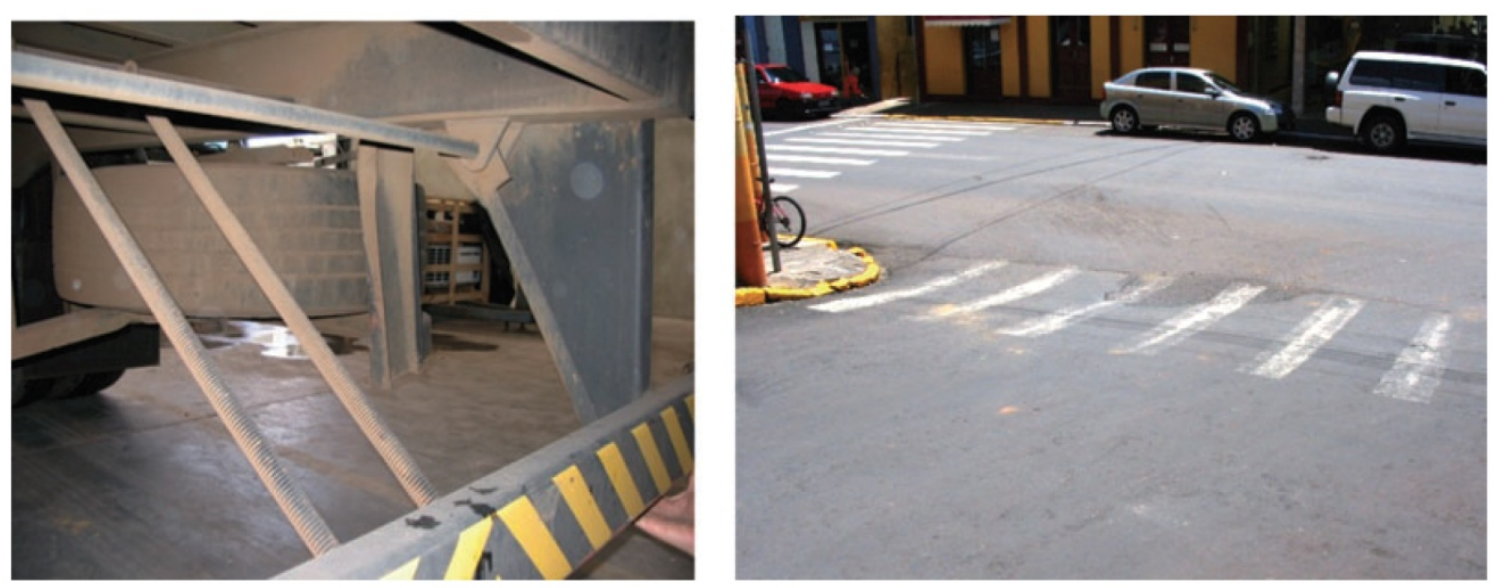
The data for this study as described earlier uses events that were triggered at $0.25 \mathrm{~g}$ intensity or higher, and, also, the recorders were in 'max overwrite' memory mode. What this entails is that the higher intensity vibrations are saved in the recorders' memory for data analysis. This results in vibration spectra that generally are 'more' severe than the 'average' intensity of vibrations that occur during the entire trip. This is a common methodology used by packaging researchers as it also allows to shorten test time as compared with travel time in the vehicle. As a result, most vibration testing for package validation is done at time intervals that are less than the actual trip but at levels representing the higher of the measured vibrations from the entire trip. Based on the time intervals of the recorded data, it is estimated that the analysed spectra represent the highest $10 \%$ of the entire trip that was monitored.

The PSD shape varies greatly according to region, truck type and load. Metropolitan measurements resulted in higher vibration intensities in the vertical direction, followed by lateral and longitudinal vibration, as stated in previous studies. ${ }^{9-11}$ Based on comparing the $G_{\text {rms }}$ for each trip, vibration levels increased with lighter loads, bad road conditions (potholes in asphalt or dirt roads) and higher speeds.

Based on the various PSD plots, a composite spectrum was developed for a vertical vibration simulation of truck vibration in Brazil. This can be used in test methods such as American Society of Testing and Materials D4728 to perform vibration testing of products. ${ }^{12}$ The composite spectrum shown in Figure 21 is the average of all previously shown spectra. Table 4 summarizes the $G_{\text {rms }}$ values for the vertical, lateral and longitudinal directions, and for the composite as well as for all individual trip PSDs.

\section{CONCLUSIONS}

Based on the results of this study, the following conclusions were reached:

1. Road conditions in Brazil vary greatly according to region and type. Metropolitan distribution resulted in lower vibration levels than interstate transport. 


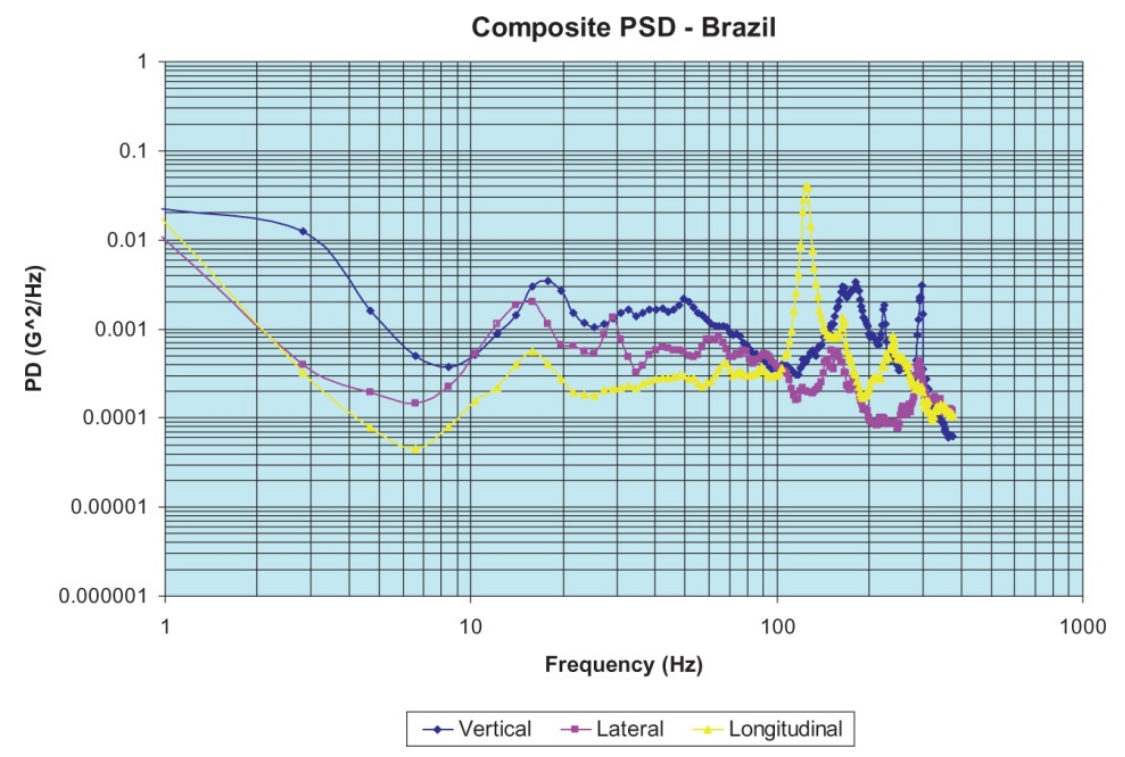

Figure 21. Composite PSD plot for all measurements. Grms: vertical $=0.6284$; lateral $=0.3714$; longitudinal $=0.7013$.

\begin{tabular}{|c|c|c|c|}
\hline \multirow[b]{2}{*}{ Location } & \multicolumn{3}{|c|}{$G_{\text {rms }}$} \\
\hline & Vertical & Lateral & Longitudinal \\
\hline \multicolumn{4}{|c|}{ Metropolitan regions } \\
\hline Passo Fundo - RS & 0.3449 & 0.2198 & 0.4438 \\
\hline Rio de Janeiro - RJ & 0.4291 & 0.3364 & 0.3092 \\
\hline Campinas - SP & 0.5591 & 0.4699 & 0.3799 \\
\hline Santos - SP & 0.7206 & 0.5377 & 0.2286 \\
\hline São Paulo - SP & 0.5706 & 0.1958 & 0.2400 \\
\hline Lages - SC & 0.3142 & 0.1608 & 0.1609 \\
\hline Curitiba - PR & 0.7621 & 0.2462 & 0.2172 \\
\hline Videira - SC & 0.4193 & 0.5100 & 0.1739 \\
\hline Goiânia - GO & 0.2127 & 0.0995 & 0.1993 \\
\hline Salvador - BA & 0.6804 & 0.4388 & 0.2508 \\
\hline \multicolumn{4}{|c|}{ Long distance trips } \\
\hline Videira (SC)-Belo Horizonte (MG) & 0.5393 & 0.1944 & 0.5798 \\
\hline Videira (SC)-Rio Verde (GO) & 0.6943 & 0.3625 & 1.6828 \\
\hline Goiânia (GO)-Salvador (BA) & 1.1239 & 0.4601 & 1.4917 \\
\hline \multicolumn{4}{|c|}{ Composite Brazil } \\
\hline All locations & 0.6284 & 0.3714 & 0.7013 \\
\hline
\end{tabular}


2. Metropolitan measurements showed the expected behaviour. The $G_{r m s}$ values for vertical, lateral and longitudinal vibration were $0.55,0.37$ and $0.3 \mathrm{G}$, respectively. Long distance measurements showed similar results up to $100 \mathrm{~Hz}$, which is the range where most products are damaged. 3. Accelerations increased with lighter loads, bad road conditions and higher speeds.

4. Cross-country data shows large amplitude vibrations above $100 \mathrm{~Hz}$. This is due to the low rear bumper contacting the road.

5. The data from this study can be used to program vibration tables to reproduce these vibration conditions for package testing.

\section{REFERENCES}

1. World Economy Outlook. Financial systems and economic cycles. World Monetary Fund, September 2006; http://www.imf.org/external/pubs/ft/weo/2006/02/index.htm [accessed 15 March 2007].

2. Applied Economic Research Institute of Brazil, IPEA. Brazilian Conjuncture Bulletin 2007; February.

3. Northoff E. Animal disease outbreaks hit global meat exports. FAO Newsroom. 2 March, 2004; http://www.fao.org/newsroom/en/news/2004/37967/index.html [accessed 1 March 2007].

4. CNT - Brazilian National Transport Confederation. Statistical bulletin of transports in Brazil. 2007; http://www.cnt.org.br/arquivos/downloads/becnt_2007_01.pdf [accessed 13 March 2007].

5. Singh SP, Joneson E. Measurement and analysis of the global distribution environment. In Proceedings of 22nd IAPRI Symposium, International Association of Packaging Research Institutes, Campinas-SP, Brazil, March 2005.

6. Baird T, Young D. The China Project: an assessment of the china shipping and handling environments. ISTA PST Newsletter 2004.

7. Singh SP, Sandhu APS, Joneson E, Singh J. Measurement and analysis of truck and rail shipping environment in India. Packag. Technol. Sci. 2007.

8. Marcondes J. Vibration. In The Wiley Encyclopedia of Packaging Technology, 2nd edn, A. Brody (ed.). John Wiley \& Sons Inc.: New York, 1997; 955-958.

9. Singh SP, Antle JR, Brugess G. Comparison between lateral, longitudinal and vertical vibration levels in commercial truck shipments. Packag. Technol. Sci. 1992; 5: 71-75.

10. Singh SP, Marcondes J. Vibration levels in commercial truck shipments as a function of suspension and payload. J. Test. Eval. 1992; 20(6): 466-469. 
11. Singh SP, Singh J, Joneson E. Measurement and analysis of U.S. truck vibration for leaf spring and air ride suspensions, and development of tests to simulate these conditions. In Proceedings of $22^{\text {nd }}$ IAPRI Symposium, International Association of Packaging Research Institutes, Campinas-SP, Brazil, March 2005.

12. Annual Book of ASTM Standards, Volume 15.09. American Society of Testing and Materials: West Conshohocken, PA; 2006. 